\title{
Stenolaemate bryozoan fauna from the Mississippian of Guadiato Area, southwestern Spain
}

\author{
Andrej ERNST ${ }^{*}$ \& Sergio RODRÍGUEZ ${ }^{2}$
}

${ }^{1}$ Institut für Geologie, Universität Hamburg, Bundesstr. 55, D-20146 Hamburg, Germany; Andrej.Ernst@uni-hamburg.de

${ }^{2}$ UEI-Departamento de Paleontología (CSIC-UCM), Facultad de Ciencias Geológicas, Universidad Complutense, Ciudad Universitaria s/n, 20816 Madrid, Spain; sergrodr@geo.ucm.es

* Corresponding author

Ernst, A. \& Rodríguez, S. 2013. Stenolaemate bryozoan fauna from the Mississippian of Guadiato Area, southwestern Spain. [Briozoos estenolemados del Misisípico del Área del Guadiato, suroeste de España]. Spanish Journal of Palaeontology, 28 (2), 173-192.

\section{ABSTRACT}

Stenolaemate bryozoan fauna from the Lower Carboniferous (Mississippian) of southwestern Spain (Los Santos de Maimona Basin and Guadiato Area - Ossa Morena Zone) contains eight bryozoan species including three cystoporates, three trepostomes, and two cryptostomes. They range from Asbian (Upper Viséan) to Pendleian (Serpukhovian). This fauna displays distinct palaeobiogeographic relationships to the Mississippian of Europe, USA, Siberia, and Japan.

Keywords: Bryozoa, taxonomy, palaeobiogeography, Mississippian, Spain.

\section{RESUMEN}

Las asociaciones del briozoos estenolemados del Misisípico (Carbonífero inferior) del suroeste de España (Cuenca de los Santos de Maimona y Área del Guadiato, Zona de Ossa Morena) se componen de ocho especies de briozoos que incluyen tres cystoporados, tres trepostomados y dos cryptostomados. Su distribución se extiende desde el Asbiense (Viseense superior) al Pendleiense (Serpujoviense). Estas asociaciones muestran distintas relaciones biogeográficas con el Misisípico de Europa, Estados Unidos, Siberia y Japón.

Palabras clave: Briozoos, taxonomía, paleobiogeografía, Misisípico, España. 


\section{INTRODUCTION}

Stenolaemate bryozoans are commonly abundant and diverse in Carboniferous deposits worldwide. They are important for biostratigraphy and palaeobiogeography (Ross, 1981; Bancroft, 1987). However, our knowledge about them is very uneven, and many of older data need to be revised. Well-studied bryozoan faunas are known from North America, certain parts of Australia, several regions in China and Mongolia, the British Isles, and the European part of Russia and Ukraine. In other regions the Carboniferous bryozoans are poorly studied.

The Lower Carboniferous (Mississippian) bryozoans in Europe were mainly recorded from the British Isles (e.g., Wyse Jackson, 1996), and from Poland and Germany (Nekhoroshev, 1932; Ernst, 2005). Mississippian bryozoans are also known from southern France, Montagne Noire (unpublished data) and southwestern Spain (present paper).

Bryozoans described in this paper have been recorded in two different basins in southwestern Spain (Sierra Morena): the Los Santos de Maimona Basin, and the Guadiato Area. These Mississippian basins contain upper Viséan and Serpukhovian deposits.

The Los Santos de Maimona Basin is located in the Badajoz province, between Los Santos de Maimona, Fuente del Maestre and Feria villages. Mississippian outcrops are $11 \mathrm{~km}$ long from SE to NW, and 1 to $3 \mathrm{~km}$ wide. Eight stratigraphic units have been defined in that basin (Fig. 1c) by Rodríguez et al. (1992). The bryozoans have been sampled from unit 1 (upper Asbian) in Los Santos Hill (SS) and El Almendro (AL) sections. Unit 1 is composed of biostromal limestones where rugose, and tabulate corals and gigantoproductid brachiopods are the most conspicuous elements in a very diverse assemblage (Rodríguez et al., 1992, 1994). Bryozoans are common in this unit, mainly in the northern outcrops (AL). Pseudonematopora planatus Wyse Jackson, 1996, Stenophragmidium crassimularis (Lee, 1912), and Nikiforovella multipitata Trizna, 1958 have been recorded there (Fig. 2).

The Guadiato Area is a large and complex region in SW Spain that comprises Mississippian siliciclastics and limestones (Fig. 1b). It is divided into three bands (Cózar \& Rodríguez, 1999): the Fresnedoso Unit, composed mainly of Viséan siliciclastic rocks described by Cózar \& Rodríguez (2001); the San Antonio-La Juliana Unit, composed of Serpukhovian siliciclastic and limestone rocks (Cózar \& Rodríguez, 2004); the Sierra del Castillo Unit, composed mainly of Viséan limestone rocks (Rodríguez et al., 2007).

The El Collado Section (about $150 \mathrm{~m}$ in thickness) comprises the upper part of the stratigraphical succession in the Castillo Ridge (Sierra del Castillo Unit), SE from Espiel. It consists of massive and well bedded limestones deposited in shallow water of an inner shelf. Corals, algae and foraminifera are common in this succession. The distribution of corals, foraminifera, algae and conodonts indicates a late Viséan age (Asbian-Brigantian). The Asbian/Brigantian boundary is located between units COL4 and COL/6 of El Collado section (Rodríguez et al., 2007). Nikiforovella multipitata Trizna, 1958 and Fistulipora incrustans (Phillips, 1836) have been recorded in El Collado Section.

The Caleras Bajas and Antolín sections are located in the northern outcrops of the Sierra del Castillo Unit, near Peñarroya-Pueblonuevo. They comprise Brigantian siliciclastic and carbonate rocks deposited in a talus/ramp. Shales and sandstones in cyclic sequences dominate in these sections, but limestone boulders, microbial mounds and conglomerates also occur (Cózar \& Rodríguez, 2000; Rodríguez \& Rodríguez-Curt, 2002). The carbonate boulders contain reefal facies rich in corals, algae and cyanobacteria. Pseudonematopora planatus Wyse Jackson, 1996, Nikiforovella multipitata Trizna, 1958, and Glyptopora michelinia (Prout, 1860) have been recorded from these outcrops.

The La Cornuda Section is located in the San-AntonioLa Juliana Unit, about $3 \mathrm{~km}$ Northwest of Espiel, near La Cornuda Farm. The coordinates at the base of the section are $5^{\circ} 6^{\prime} 30^{\prime \prime}$ West and $38^{\circ} 12^{\prime} 40^{\prime \prime}$ North. It was first described by Cózar (1998), who analysed the age and paleoenvironment of each unit based on algae, foraminifera and microfacies. He identified foraminifera zones 17 and 18 of Mamet (1974), included in the Pendleian stage (lower Serpukhovian). The section is about $500 \mathrm{~m}$ thick, but only some limestones, calcareous sandstones and conglomerates are exposed. Cózar (1998) and Cózar \& Rodríguez (2004) regarded the whole sequence having originated on a shallow platform where bioclastic limestones, calcareous sandstones and conglomerates represent shoals while the covered units (lutites, limolites and marls) represent surrounding lagoonal and shallow platform facies. Gómez-Herguedas \& Rodríguez (2005) studied the coral assemblages and later analysed the palaeoenvironments (Gómez-Herguedas \& Rodríguez, 2008). The following bryozoans have been recorded from the La Cornuda Section: Stenophragmidium crassimularis (Lee, 1912), S. paramirandum Ernst et al., 2005, Fistulipora sp., and Hinaclema hinaensis Sakagami \& Sugimura, 1987.

\section{MATERIAL AND METHODS}

Bryozoans were investigated in thin sections using a binocular microscope in transmitted light. Morphologic character terminology is partly adopted from Anstey \& Perry (1970) for trepostomes and from Hageman (1993) for cryptostomes. Thin sections are deposited at the Universidad Complutense, Madrid. 

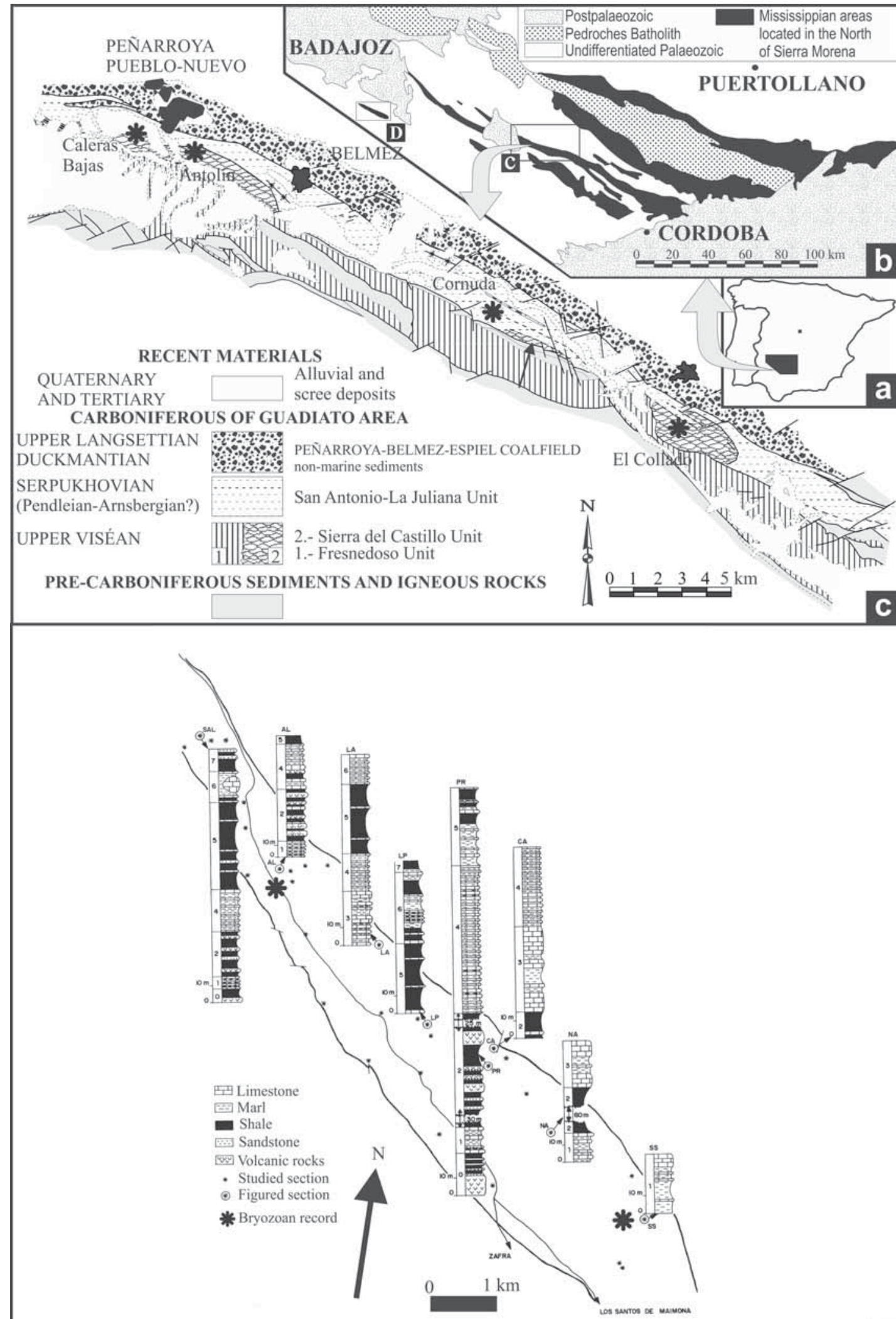

Figure 1. Location of the studied sections. a) Map of the Iberian Peninsula. b) Distribution of Carboniferous outcrops in the Ossa Morena Zone. c) Mississippian outcrops in the Guadiato Area. Asterisks show the position of the studied sections. d) Mississippian outcrops in the Los Santos de Maimona Basin. Asterisks show the position of the studied sections. SALSalamanco Chico Section. AL- El Almendro Section. LA- La Alameda Section. LP- Las Pilitas Section. PR- Portezuelo Section. CA- Cerro Almeña Section. NA- Navafría Section. SS- Los Santos Section. 


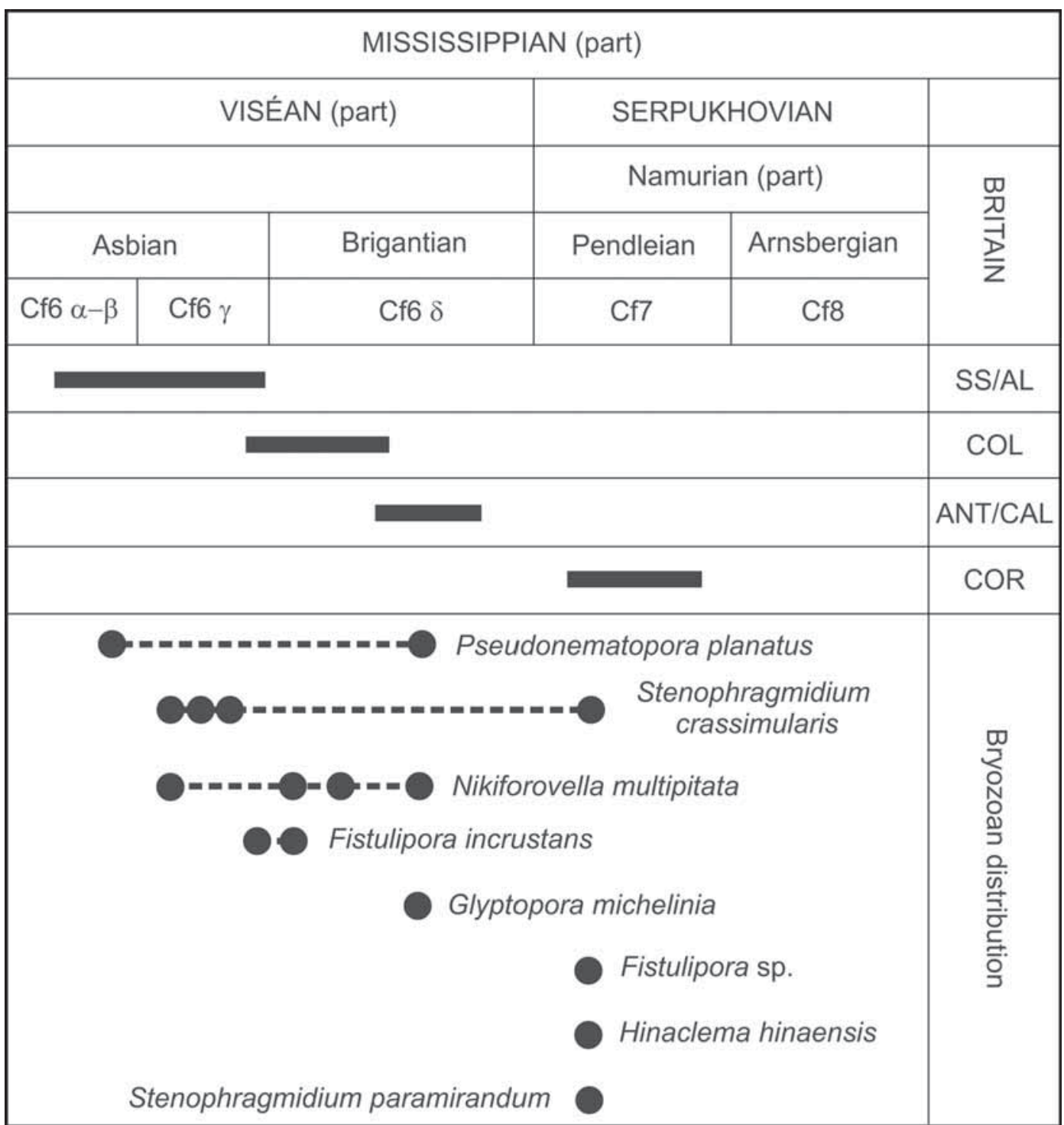

Figure 2. Stratigraphic distribution of the studied sections with location of the identified taxa. SS/AL - Los Santos and El Almendro Sections. COL - El Collado Section. ANT/CAL - Antolín and Caleras Bajas Sections. COR - La Cornuda Section.

\section{SYSTEMATIC PALAEONTOLOGY}

Phylum BRYOZOA Ehrenberg, 1831

Class STENOLAEMATA Borg, 1926

Order CYSTOPORATA Astrova, 1964

Suborder FISTULIPORINA Astrova, 1964

Family Fistuliporidae Ulrich, 1882

Genus Fistulipora M’Coy, 1849

Type species. Fistulipora minor M'Coy, 1849. Carboniferous; England.

Diagnosis. Massive, encrusting or ramose colonies. Cylindrical autozooecia with thin walls and complete diaphragms. Apertures rounded, possessing horse-shoe shaped lunaria. Autozooecia separated by the extrazooidal vesicular skeleton.
Comparison. Fistulipora M'Coy, 1849 differs from Eridopora Ulrich, 1882 in having rounded, horseshoeshaped lunaria instead of triangular ones. Furthermore, Eridopora develops persistently encrusting colonies, whereas Fistulipora may also develop massive and branched colonies.

Stratigraphic and geographic range. Ordovician to Permian; worldwide.

Fistulipora sp.

(Figs 3a-3d; Table 1)

Material. Cor/1-51, Cor/1-86. 

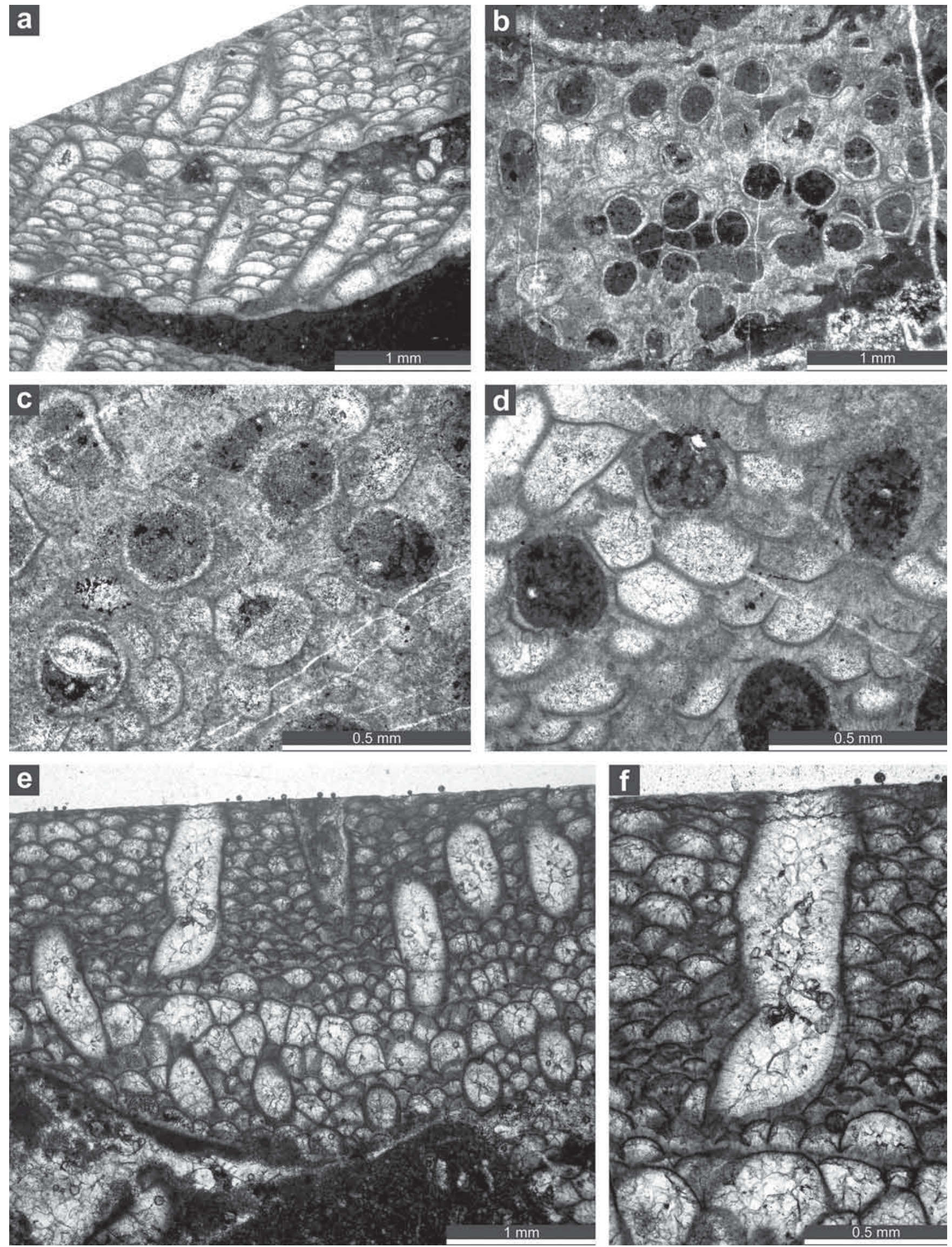

Figure 3. Fistulipora sp. 1: a) Longitudinal section, Cor/1-51. b-c) Tangential section, Cor/1-86. d) Tangential section, Cor/1-51. Fistulipora incrustans (Phillips, 1836): e-f) Longitudinal section, Col/1-11. 
Table 1. Descriptive statistics of Fistulipora sp. Abbreviations: $\mathrm{N}=$ number of measurements, $\mathrm{X}=$ mean, $\mathrm{SD}=$ sample standard deviation, $\mathrm{CV}=$ coefficient of variation, $\mathrm{MIN}=$ minimal value, $\mathrm{MAX}=$ maximal value.

\begin{tabular}{lcccccc}
\hline & $\mathbf{N}$ & $\mathbf{X}$ & SD & CV & MIN & MAX \\
\hline Aperture width, mm & 10 & 0.23 & 0.030 & 12.93 & 0.19 & 0.29 \\
$\begin{array}{l}\text { Autozooecial aperture } \\
\text { spacing, mm }\end{array}$ & 10 & 0.40 & 0.063 & 15.86 & 0.32 & 0.53 \\
Vesicle diameter, mm & 10 & 0.16 & 0.057 & 36.12 & 0.08 & 0.29 \\
Vesicles per aperture & 5 & 7.8 & 0.837 & 10.73 & 7.0 & 9.0 \\
\hline
\end{tabular}

Description. Encrusting colony, 1.0-1.1 mm thick. Basal diaphragms common, 2-4 per autozooecium. Autozooecial apertures circular, $0.18-0.22 \mathrm{~mm}$ wide. Lunaria weakly developed. Vesicles large, flattened, 8-9 surrounding each autozooecia aperture, with rounded roofs, polygonal in tangential section, separating the autozooecia in single row, 11-12 per $1 \mathrm{~mm}$ line in longitudinal section.

Comparison. The present species differs from Fistulipora incrustans (Phillips, 1836) by having smaller autozooecial apertures $(0.18-0.22 \mathrm{~mm}$ vs. $0.25-0.36 \mathrm{~mm}$ in $F$. incrustans) and by fewer vesicles around autozooecial apertures (8-9 instead of 10-14 in F. incrustans). It differs from Fistulipora excelens Urlich, 1884 from the Mississippian of USA in having smaller autozooecia (0.18$0.22 \mathrm{~mm}$ vs. $0.30-0.40 \mathrm{in} F$. excelens). The present material is inadequate for establishing a new species, however.

Stratigraphic and geographic range. Carboniferous, Mississippian, Serpukhovian (Pendleian); La Cornuda, southwestern Spain.

Fistulipora incrustans (Phillips, 1836)

(Figs 3e-3f, 4a-4b; Table 2)

Material. Val-1-7, Col/1-11, Col/2b-1, Col/7-11.

Table 2. Descriptive statistics of Fistulipora incrustans (Phillips, 1836). Abbreviations as for Table 1.

\begin{tabular}{lcccccc}
\hline & $\mathbf{N}$ & $\mathbf{X}$ & SD & CV & MIN & MAX \\
\hline Aperture width, mm & 26 & 0.30 & 0.026 & 8.69 & 0.25 & 0.36 \\
$\begin{array}{l}\text { Autozooecial aperture } \\
\text { spacing, mm }\end{array}$ & 25 & 0.49 & 0.060 & 12.33 & 0.36 & 0.63 \\
Vesicle diameter, mm & 20 & 0.13 & 0.022 & 17.07 & 0.10 & 0.18 \\
Vesicle spacing, mm & 20 & 0.10 & 0.025 & 25.27 & 0.05 & 0.13 \\
\hline
\end{tabular}

Description. Encrusting colony, 1.5-3.1 mm thick. Diaphragms abundant in basal parts of autozooecia, rare to common in distal exozone. Autozooecial apertures circular to ovate. Lunaria weakly developed, horseshoeshaped. Vesicles large, 10-14 surrounding each autozooecia aperture, with rounded roofs, polygonal in tangential section, 1-3 rows separating the autozooecia, 9-12 spaced per $1 \mathrm{~mm}$ line in longitudinal section.

Comparison. Fistulipora incrustans (Phillips, 1836) is similar to both F. parvilabrum Shulga-Nesterenko, 1955 and F. steshevensis Shulga-Nesterenko, 1955 from the Mississippian of the Russian Platform. Fistulipora incrustans differs from both species by having smaller vesicles (10-14 of them surrounding autozooecial aperture versus 7-8 in F. parvilabrum and 8-9 in F. steshevensis). Fistulipora incrustans (Phillips, 1836) differs from F. micidolamina McKinney, 1972 from the Mississippian of USA (Serpukhovian) and Pennsylvanian of NW Spain (Bashkirian-Moscovian) by having larger autozooecial apertures (average width $0.30 \mathrm{~mm}$ vs. $0.25 \mathrm{~mm}$ in $F$. micidolamina).

Remark. See full synonymy of Fistulipora incrustans (Phillips, 1836) in Bancroft \& Jackson (1995, p. 131133).

Stratigraphic and geographic range. Carboniferous, Mississippian, Viséan (Asbian-Brigantian); England, Scotland, Ireland. Carboniferous, Mississippian, Viséan (Asbian-Brigantian); El Collado, southwestern Spain.

Suborder HEXAGONELLINA Morozova, 1970

Family Hexagonellidae Crockford, 1947

Genus Glyptopora Ulrich, 1884

Type species. Coscinium plumosum Prout, 1860. Carboniferous, Mississippian; USA (Illinois).

Diagnosis. Colony consisting of erect bifoliate lobes. Mesotheca with dark, thin, middle layer and two light and thick outer layers, containing median rods and longitudinal ridges parallel to growth direction. Autozooecia recumbent on the mesotheca or epitheca for a long distance, bending upwards abruptly or gently, intersecting the surface almost perpendicularly. Hemisepta absent. Thin, complete diaphragms common to abundant. Autozooecial apertures circular to oval. Lunaria common. Autozooecia separated by vesicular skeleton that is covered in distally by calcite material. Microacanthostyles in outer layer of calcite material. Maculae depressed, long, narrow, consisting of stereom.

Comparison. Glyptopora differs from Evactinopora Meek \& Worthen, 1865 by lacking hemisepta, and from 
Prismopora Hall, 1883 by possessing median tubuli in the mesotheca and lacking hemisepta.

Remark. Prismopora species described from the Carboniferous and Lower Permian deposits of Europe (Ernst, 2000; Ernst \& Winkler Prins, 2008) differ significantly from the type species Prismopora triquetra Hall \& Simpson, 1887 from the Middle Devonian of North America. The most important differences include the presence of long hemisepta, poorly developed vesicular skeleton consisting of small, rare, vesicles, and lacking rods. Prismopora species described by Crockford (1957) from the Lower Permian of Australia, are similar to the material from Europe (especially Prismopora digitata Crockford, 1957), and differ in the same manner from the type species. They may belong to the genus Glyptopora.

Stratigraphic and geographic range. CarboniferousPermian; North America, Europe, Australia.

Glyptopora michelinia (Prout, 1860)

(Figs 4c-4e, 5a-5f, 6a-6d; Table 3)

1860 Coscinium michelinia Prout, p. 573.

1866 Coscinium michelinia Prout, 1860; Prout, p. 414, pl. 22, figs 4 , 4o.

1890 Glyptopora michelinia (Prout, 1860); Ulrich, p. 515-516, pl. 78, figs 8-8b.

Material. Ant 2/1-1, Ant 2/1-9, Ant 2/1-25, Ant 2/1-1, Ant 2/1-45, Ant 2/1-47, Ant 2/1-F2, FE-A.

Table 3. Descriptive statistics of Glyptopora michelinia (Prout, 1860). Abbreviations as for Table 1.

\begin{tabular}{lcccccc}
\hline & $\mathbf{N}$ & $\mathbf{X}$ & SD & CV & MIN & MAX \\
\hline Aperture width, mm & 30 & 0.14 & 0.019 & 13.84 & 0.10 & 0.18 \\
Autozooecial aperture & 30 & 0.37 & 0.045 & 12.10 & 0.30 & 0.48 \\
spacing, mm & & & & & & \\
Vesicle diameter, mm & 30 & 0.09 & 0.020 & 21.31 & 0.06 & 0.13 \\
Vesicles per aperture & 15 & 8 & 1.134 & 14.17 & 6 & 10 \\
Vesicle spacing, mm & 10 & 0.07 & 0.007 & 10.69 & 0.06 & 0.08 \\
\hline
\end{tabular}

Description. Colony initially encrusting, producing a series of erect bifoliate lobes. Lobes usually trifurcating radially and fused together forming a honeycomb-shaped structure. Lobes diverg radially from the central axis at angles of $86-148^{\circ}$. Bifoliate lobes up to $5 \mathrm{~mm}$ high and 0.6-0.9 mm thick. Mesotheca with a dark, thin, middle layer and two light, thick, outer layers, $0.025-0.050 \mathrm{~mm}$ thick, containing abundant median tubuli. Median tubuli of hyaline calcite, rounded in transverse section, $0.010-0.015$ $\mathrm{mm}$ in diameter, developing short and densely spaced lateral projections (Figs 4c-4d). Autozooecia recumbent on the mesotheca or epitheca for a relatively long distance, then bending upwards abruptly, intersecting the surface almost perpendicularly. Thin, complete diaphragms in autozooecia occasionally present. Autozooecial apertures circular to oval. Lunaria weakly developed, horseshoe-shaped to triangular. Vesicular skeleton well developed, covered distally by calcite material. Vesicles moderately large, polygonal in tangential section, with 6-10 surrounding each autozooecial aperture, and 1-3 rows between autozooecia in longitudinal sections, with rounded roofs. Longitudinal depressed maculae lacking autozooecia apparently developed only near bases of erect lobes along the axis of fusion.

Comparison. Glyptopora michelinia (Prout, 1860) differs from Glyptopora plumosa (Prout, 1860) by mode of lobe divergence. Glyptopora michelinia produced cups by lobes attached to a substrate, whereas lobes in G. plumosa arose from a common base, bifurcating and trifurcating to produce cups. Furthermore, maculae are less strongly developed, diaphragms less common and autozooecial apertures are smaller $(0.10-0.18 \mathrm{~mm}$ vs. $0.15-0.20 \mathrm{~mm}$ in G. plumosa).

Stratigraphic and geographic range. Carboniferous, Mississippian, Viséan; USA Illinois, Missouri, Virginia. Carboniferous, Mississippian, Viséan (Brigantian); Antolín section, southwestern Spain. Las Llacerias Formation, Carboniferous, Pennsylvanian, Kasimovian; Asturias, Cantabrian Mountains, NW Spain.

Order TREPOSTOMATA Ulrich, 1882

Family Stenoporidae Waagen \& Wentzel, 1886

Genus Stenophragmidium Bassler, 1952

Type species. Stenophragma lobatum Munro, 1912. Carboniferous, Mississippian, Viséan; England.

Diagnosis. Encrusting, rarely ramose, colonies. Autozooecia possessing rounded-polygonal and oval apertures. Hemiphragms short, often curved proximally, positioned on one side of autozooecia. Exilazooecia rare. Acanthostyles both large and small, rarely one size. Exozonal walls laminated, merged, without distinct autozooecial boundaries, with moniliform thickenings.

Comparison. Stenophragmidium Bassler, 1952 is similar to Tabulipora Young, 1883 in having moniliform walls and acanthostyles of two sizes, but differs from it by having hemiphragms instead of ring septa. Stenophragmidium differs from Stenopora Lonsdale, 1844 by having both hemiphragms and diaphragms: Stenopora lacks any kind of diaphragms. 

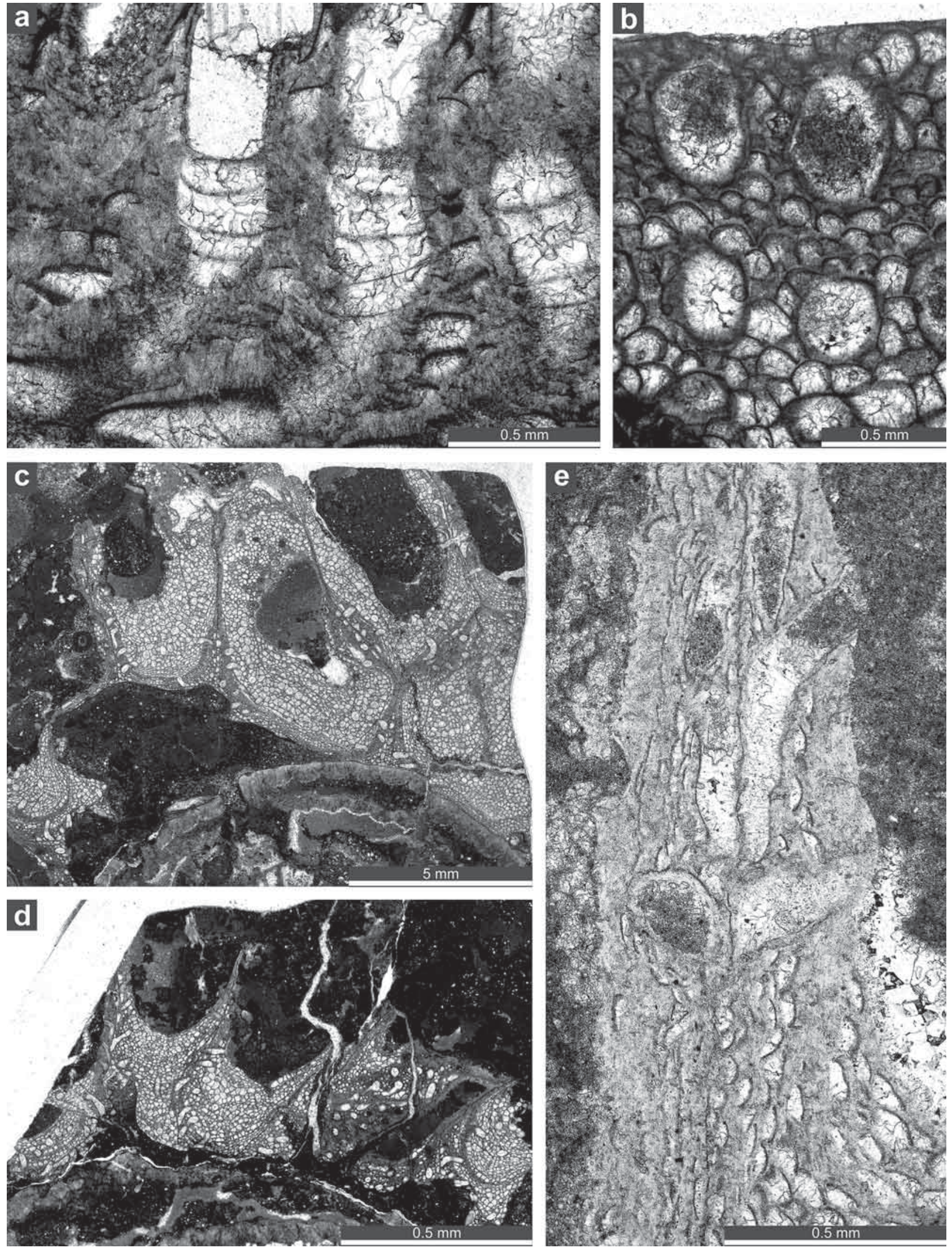

Figure 4. Fistulipora incrustans (Phillips, 1836): a) Longitudinal section showing abundant diaphragms in basal parts of zooecia, Col/7-11. b) Tangential section, Col/1-11. Glyptopora michelinia (Prout, 1860): c) Tangential section showing trifurcating lobes, Ant 2-1-45. d) Oblique section showing arising lobes, Ant 2-1-45. e) Longitudinal section of a lobe showing autozooecia and vesicular skeleton, Ant 2-1-25. 

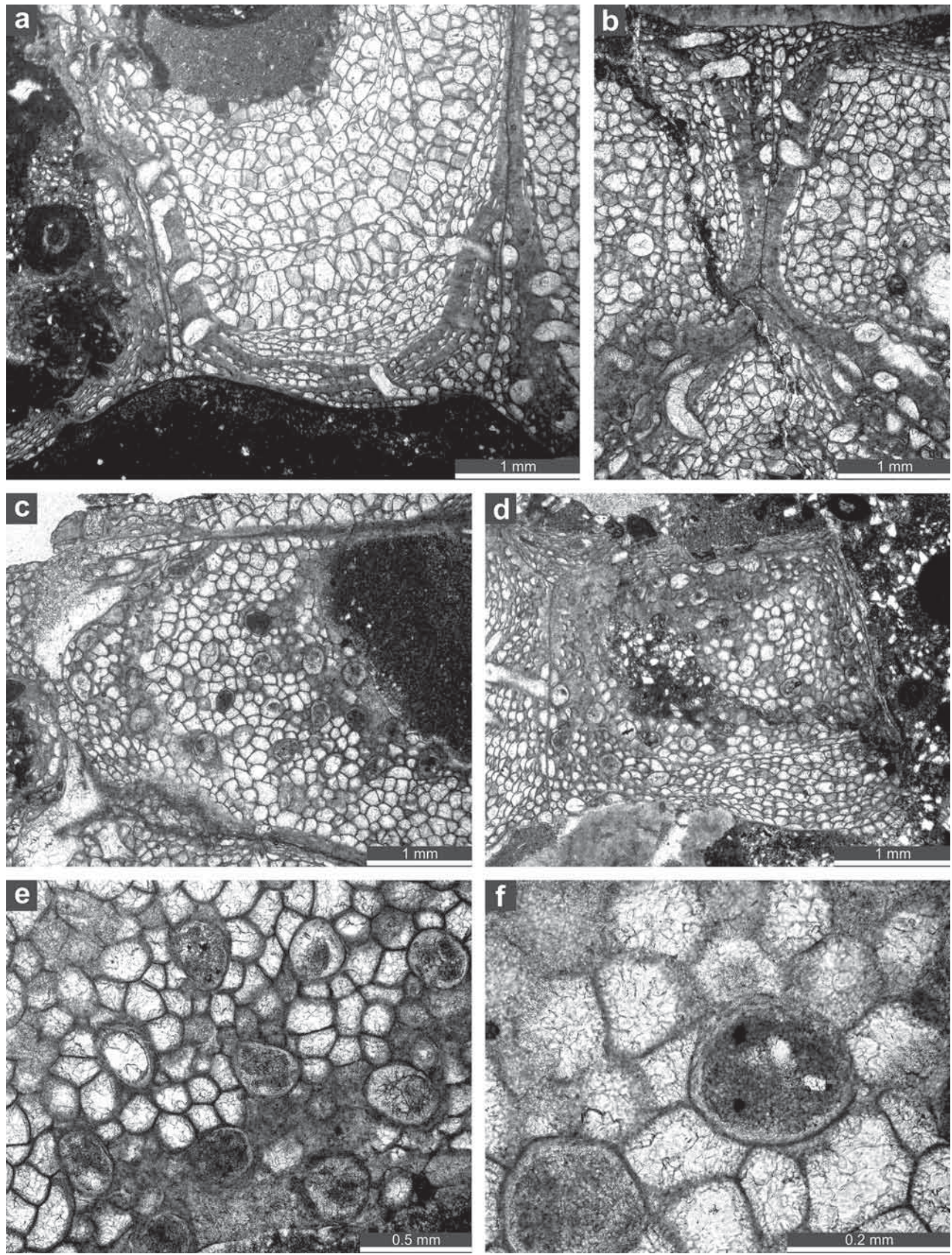

Figure 5. Glyptopora michelinia (Prout, 1860): a) Oblique section showing arising lobes and vesicular skeleton, Ant 2-1-45. b) Tangential section showing place of trifurcation, Ant 2-1-45. c) Tangential section showing part of the colony between lobes, Ant 2-1-45. d) Tangential section showing sector between fusing lobes, Ant 2-54. e-f) Tangential section showing autozooecial apertures, Ant 2-1-45. 

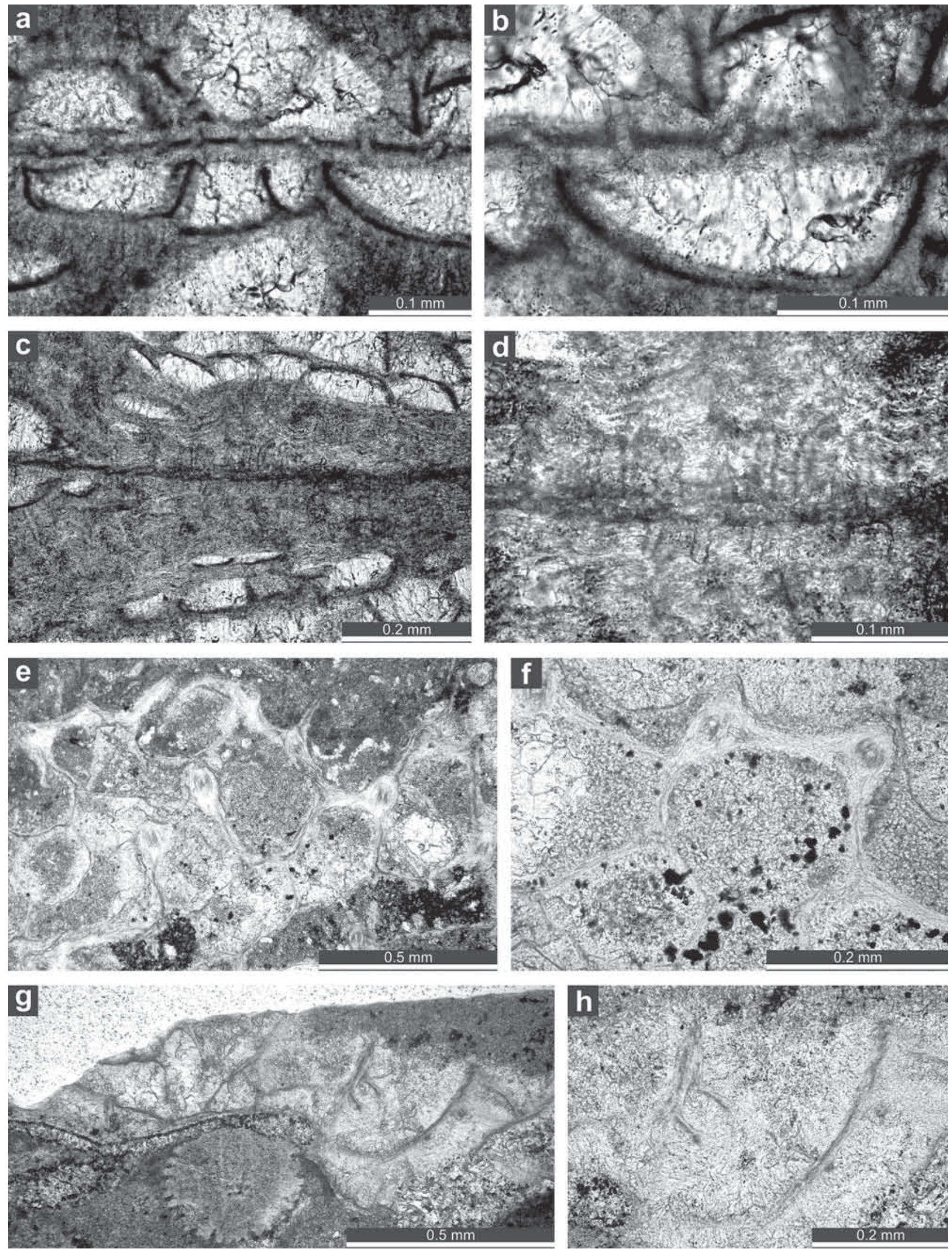

Figure 6. Glyptopora michelinia (Prout, 1860): a-b) Transverse section of a lobe showing three-layered mesotheca with median tubuli, Ant 2-1-45. c-d) Longitudinal section showing median tubuli with lateral projections, Ant 2-1-45. Stenophragmidium paramirandum Ernst et al. 2005: e-f) Oblique section showing autozooecial apertures and acanthostyles, Cor/1-60. g-h) Longitudinal section showing hemiphragms in autozooecia, Cor/1-62. 
Stratigraphic and geographic range. Lower Carboniferous to Lower Permian; Europe, North America, China, Russia.

\section{Stenophragmidium paramirandum Ernst et al., 2005} (Figs 6e-6h)

2005 Stenophragmidium paramirandum Ernst et al., p. 306, pl. 1, fig. 7, pl. 2, fig. 1, pl. 3, fig. 4

Material. Cor/1-46, Cor/1-60, Cor/1-62.

Description. Thin encrusting colonies, $0.27-0.45 \mathrm{~mm}$ thick. Autozooecia bud from a thin epitheca, bending gently in their deeper portion and intersecting the colony surface at angles of $80-90^{\circ}$. Hemiphragms thick, on proximal side of autozooecia, typically 3-4 per autozooecium. Autozooecial apertures polygonal, 0.18-0.22 mm wide. Exilazooecia not observed. Acanthostyles large, having hyaline cores and wide laminated sheaths, located in autozooecial corners, 0.06-0.09 $\mathrm{mm}$ in diameter, 2-5 per autozooecial aperture. Smaller styles occur between acanthostyles. Autozooecial walls laminated, 0.03-0.04 $\mathrm{mm}$ thick in exozone.

Comparison. Stenophragmidium paramirandum Ernst et al., 2005 differs from S. mirandum Dunaeva, 1964 from the Lower Carboniferous (Namurian) of the Ukraine by forming thinner colonies with strongly differentiated acanthostyles and smaller autozooecial aperture widths (0.18-0.22 $\mathrm{mm}$ in present material and $0.12-0.21 \mathrm{~mm}$ in type material vs. $0.27-0.30 \mathrm{~mm}$ in $S$. mirandum). Stenophragmidium paramirandum differs from $S$. lobatum (Munro, 1912) by having encrusting colony form rather than hollow erect and lobate one in the latter species, and in smaller autozooecial apertures $(0.18-0.22 \mathrm{~mm}$ vs. 0.18 $0.31 \mathrm{~mm}$ in S. lobatum).

Stratigraphic and geographic range. San Emiliano Formation, Pennsylvanian, Bashkirian; NW Spain. Mississippian, Serpukhovian (Pendleian); La Cornuda, southwestern Spain.

Stenophragmidium crassimularis (Lee, 1912) (Figs 7a-7f; Table 4)

1912 Tabulipora crassimularis Lee, pp. 172-173, pl. 16, figs. 5-6.

1912Stenophragma grandiense Munro, pp. 576-577.

2007Stenophragmidium crassimularis (Lee, 1912); Cleary \& Wyse Jackson, pp. 12-15, figs 3C-D.

Material. AL/1-3, AL/1-7, AL/1-5, AL/1-15, Ex-1, Cor/1-51, Cor/1-96.
Table 4. Descriptive statistics of Stenophragmidium crassimularis (Lee, 1912). Abbreviations as for Table 1.

\begin{tabular}{lcccccc}
\hline & $\mathbf{N}$ & $\mathbf{X}$ & SD & CV & MIN & MAX \\
\hline Colony thickness, mm & 10 & 1.25 & 0.482 & 38.50 & 0.75 & 2.50 \\
$\begin{array}{l}\text { Aperture width, mm } \\
\text { Autozooecial aperture }\end{array}$ & 35 & 0.16 & 0.032 & 19.59 & 0.10 & 0.24 \\
$\begin{array}{l}\text { spacing, mm } \\
\text { Exilazooecia width, mm }\end{array}$ & 15 & 0.041 & 0.046 & 14.48 & 0.20 & 0.42 \\
$\begin{array}{l}\text { Exozonal wall } \\
\text { thickness, mm }\end{array}$ & 19 & 0.14 & 0.036 & 25.46 & 0.08 & 0.19 \\
$\begin{array}{l}\text { Macroacanthostyle } \\
\text { diameter, mm }\end{array}$ & 6 & 0.071 & 0.006 & 8.25 & 0.060 & 0.075 \\
\hline
\end{tabular}

Description. Colonies tubular-shaped, 4-8 $\mathrm{mm}$ in diameter, produced by encrusting of ephemeral cylindrical objects (sheets $0.75-2.50 \mathrm{~mm}$ thick). Secondary overgrowth occur. Autozooecia bud from thick epitheca, bending gently in their deeper portion and intersecting the colony surface at angles of $80-90^{\circ}$. Thick hemiphragms common, 1-3 in each autozooecium, positioned on proximal side of autozooecia, and curved proximally, concentrated in the early exozone. Autozooecial apertures polygonal. Basal diaphragms rare, thin. Exilazooecia usually absent, locally rare to common. Macroacanthostyles usually absent; locally common, large (0.060-0.075 $\mathrm{mm}$ in diameter), having hyaline cores and wide laminated sheaths, positioned in autozooecial corners. Abundant microacanthostyles (heterostyles) protruding from exozonal walls perpendicular to skeletal laminations, and irregularly arranged, $0.015-0.030 \mathrm{~mm}$ in diameter. Autozooecial walls finely laminated, $0.005-0.015 \mathrm{~mm}$ thick in the endozone; laminated, merged, displaying inverted U-shaped laminations, with local monilae-like thickenings, $0.08-0.19 \mathrm{~mm}$ thick in the exozone.

Comparison. Stenophragmidium crassimularis (Lee, 1912) is similar to S. multitabulata (Lee, 1912) from the Mississippian of the British Isles, but differs from it in forming hollow ramose instead of solid ramose colonies, in having fewer abundant hemiphragms (1-6 vs. 6-7 hemiphragms per autozooecium, in autozooecial walls that are distinctly moniliform; walls in S. multitabulata lack moniliform thickenings. Stenophragmidium crassimularis is similar to S. isospinosum Ernst et al., 2005 from the Pennsylvanian of NW Spain, but differs from it by having two types of acanthostyles, instead of just microacanthostyles in S. isospinosum, and in smaller autozooecial diameters (average width $0.16 \mathrm{~mm}$ vs. 0.21 $\mathrm{mm}$ in S. isospinosum).

Stratigraphic and geographic range. Lower Carboniferous, Mississippian, Viséan (?Courceyan/ Chadian-Brigantian sub-stages); Pembrokeshire, Wales. 

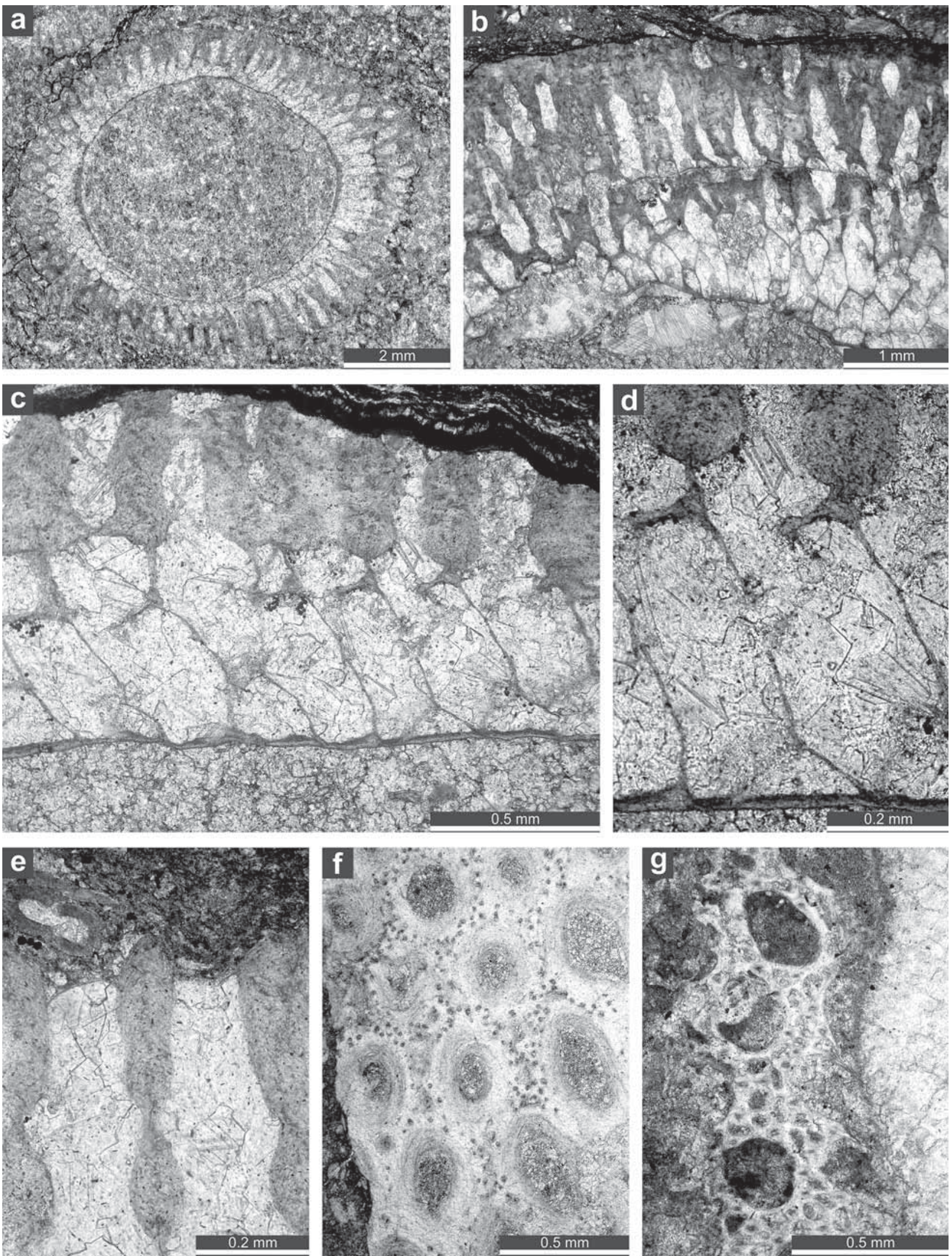

Figure 7. Stenophragmidium crassimularis (Lee, 1912): a) Transverse section of a tubular colony, Al/1-15. b) Longitudinal section of a multilayered encrusting colony, Al/1-7. c-d) Longitudinal section showing autozooecia with hemiphragms, A/1-7. e) Longitudinal section showing monilae-shaped thickenings, Al/1-7. f) Tangential section showing autozooecial apertures, microacanthostyles and a few macroacanthostyles (arrow), Al/1-5. Hinaclema hinaensis Sakagami \& Sugimura, 1987: g) Tangential section showing autozooecia, mesozooecia, and acanthostyles, Cor/1-51. 
North Yorkshire, Westmorland and Cumbria, northern England. Lower Carboniferous, Mississippian, Viséan (upper Asbian); El Almendro section, southwestern Spain. Mississippian, Serpukhovian (Pendleian); La Cornuda, southwestern Spain.

Family Crustoporidae Dunaeva \& Morozova, 1967 Genus Hinaclema Sakagami \& Sugimura, 1987

Type species. Hinaclema hinaensis Sakagami \& Sugimura, 1987. Mississippian, Viséan; Japan.

Diagnosis. Colony lamellar, encrusting with secondary overgrowth. Cylindrical autozooecia recumbent at their bases, bending sharply in exozones, intersecting the colony surface at right angles. Basal diaphragms in autozooecia rare to common. Exilazooecia abundant, separating autozooecia in multiple rows. Acanthostyles abundant throughout the colony, usually large, originating at the base of exozone. Autozooecial walls finely laminated, merged, without visible boundaries.

Comparison. Hinaclema Sakagami \& Sugimura, 1987 differs from Crustopora Dunaeva, 1964 by having large acanthostyles, instead of small needle-like ones, and displaying abundant exilazooecia. Toulopora Nakrem et al., 2009 differs in having of acanthostyles of two sizes: sparsely distributed large ones, and a row of regularly distributed small ones inflecting each zooecial aperture.

The affinity of Hinaclema is disputable because of its cylindrical zooecia with rounded apertures and finely laminated walls. Sakagami \& Sugimura (1987) placed their genus in the Family Heterotrypidae Nicholson, 1881. However, the merged wall structure, without distinct boundaries, and exilazooecia (not mesozooecia as in the original diagnosis) are not characteristic of heterotrypid bryozoans. Gorjunova (1996) placed Hinaclema in the Order Cystoporata based on its oval to circular autozooecial apertures and argued that its exilazooecia represented a special type of heterozooecia, called neozooecia. However, neozooecia have circular shape in transverse section, whereas Hinaclema's exilazooecia are polygonal, and its wall structure differs from that of cystoporate bryozoans. Schastlivtseva (1991) put Hinaclema in the Family Crustoporidae Dunaeva \& Morozova, 1967, and compared it with Crustopora Dunaeva, 1964. This assignment appears to be valid and is followed in this paper.

Stratigraphic and geographic range. Mississippian, Viséan; Japan, Uzbekistan. Mississippian, Serpukhovian (Pendleian); La Cornuda, southwestern Spain.

Hinaclema hinaensis Sakagami \& Sugimura, 1987 (Figs 7g, 8a-8c)
1987 Hinaclema hinaensis Sakagami \& Sugimura, pp 247-249, figs 1-6.

Material. Cor/1-51, Cor/1-90, PR-19.

Description. Colony lamellar, encrusting, 0.31-0.34 $\mathrm{mm}$ thick. Cylindrical autozooecia recumbent at their bases, bending sharply in exozones and intersecting the colony surface at right angles. Basal diaphragms common, 1-3 in each autozooecium. Autozooecial apertures rounded to oval, 0.18-0.22 mm wide. Exilazooecia abundant, 1-4 rows separating autozooecia, rounded-polygonal in tangential section, originating at the base of the exozone, 0.03-0.08 $\mathrm{mm}$ in diameter. Acanthostyles abundant throughout the colony, originating at the base of the exozone, having narrow hyaline cores and wide laminated sheaths, 0.03$0.04 \mathrm{~mm}$ in diameter. Autozooecial walls finely laminated, merged, without visible boundaries and monilae-shaped thickenings, $0.015-0.030 \mathrm{~mm}$ thick.

Comparison. Hinaclema hinaensis Sakagami \& Sugimura, 1987 differs from H. sakagamai Schastlivtseva, 1991 from the Mississippian (Viséan) of Uzbekistan by having smaller autozooecial widths $(0.18-0.22 \mathrm{~mm}$ in our material, 0.19-0.28 $\mathrm{mm}$ in Japanese material, vs. 0.35-0.40 $\mathrm{mm}$ in H. sakagamai).

Stratigraphic and geographic range. Mississippian, Viséan; Japan. Mississippian, Serpukhovian (Pendleian); La Cornuda, southwestern Spain.

Order CRYPTOSTOMATA Vine, 1884

Suborder RHABDOMESINA Astrova \& Morozova, 1956

Family Arthrostylidae Ulrich, 1882

Genus Pseudonematopora Balakin, 1974

Type species. Nematopora? turkestanica Nikiforova, 1948. Lower Carboniferous of the Middle Asia.

Diagnosis. Ramose colonies with occasional dichotomous branches. Branches width constant, circular to semicircular in transverse section. Autozooecia arranged in 6 to 16 longitudinal rows, budding in an annular manner from a central axis or median wall. Autozooecial apertures circular to oval shaped, with proximal peristomes. Vesicular skeleton may be present in the exozone. Diaphragms and acanthostyles absent, terminal diaphragms common.

Comparison. Pseudonematopora Balakin, 1974 differs from Nematotrypa Bassler, 1911 by lacking both hemidiaphragms in autozooecia and nodes on colony surfaces. 

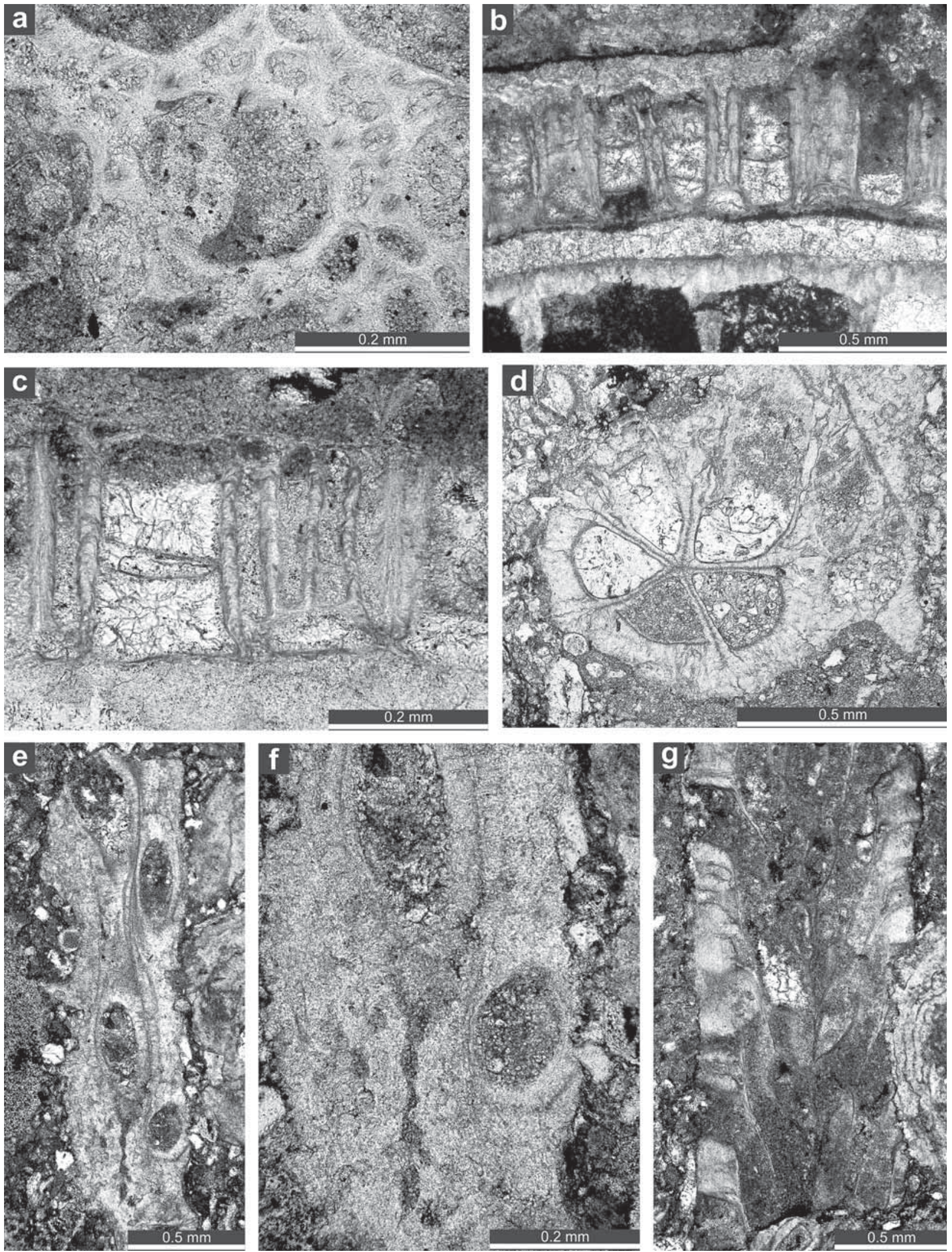

Figure 8. Hinaclema hinaensis Sakagami \& Sugimura, 1987: a) Tangential section showing autozooecia, mesozooecia, and acanthostyles, Cor/1-51. b) Longitudinal section showing autozooecia and mesozooecia, Cor/1-51. c) Longitudinal section showing autozooecia and mesozooecia, Cor/1-90. Pseudonematopora planatus Wyse Jackson, 1996: d) Transverse section, $\mathrm{Col} / 2 \mathrm{~b}$. e-f) Tangential section showing autozooecial apertures, Col/2b. Nikiforovella multipitata Trizna, 1958: g) Longitudinal section, $\mathrm{Cal} / 2 \mathrm{~b}$. 
Stratigraphic and geographic range. Upper Devonian (Famennian) to Pennsylvanian (Bashkirian); Europe, Russia, Kazakhstan, China, Mongolia.

Pseudonematopora planatus Wyse Jackson, 1996 (Figs 8d-8f)

1996Pseudonematopora planatus Wyse Jackson, p. 126-127, fig 3c, 10-15.

2005 Pseudonematopora planatus Wyse Jackson, 1996; Ernst, p. 59, figs 4C-G.

Material. 36894, Cal/2b-10, SSc 1/14-1.

Description. Ramose colony, circular or slightly angular in cross-section, $0.66-0.72 \mathrm{~mm}$ in diameter. Short autozooecia budding in spiral order from the central axis. Hemisepta absent; terminal diaphragms common. Autozooecial apertures oval to teardrop-shaped, 0.12-0.13 $\mathrm{mm}$ wide, arranged in regular diagonal rows. Autozooecia displaying two types of walls - inner, bright, granularprismatic walls and outer, dark, laminated walls. The inner granular-prismatic walls building three-layered endozone walls consisting of two bright outer layers and the dark inner one. No heterozoecia or styles present.

Comparison. Pseudonematopora planatus Wyse Jackson, 1996 differs from P. turkestanica (Nikiforova, 1948) from the Mississippian (Viséan) of Kazakhstan by having thinner branches $(0.66-0.72 \mathrm{~mm}$ vs. $0.80-2.80 \mathrm{~mm})$, smaller apertures (0.12-0.13 mm vs. $0.17-0.22 \mathrm{~mm})$, and by laking heterozooecia. Pseudonematopora planatus differs also from P. balakini Gorjunova, 1988 from the Pennsylvanian (Bashkirian) of Mongolia in having thinner branches $(0.66-0.72 \mathrm{~mm}$ vs. $0.88-1.10 \mathrm{~mm})$, smaller apertural width $(0.12-0.13 \mathrm{~mm}$ vs. $0.18-0.22 \mathrm{~mm})$, and by laking heterozooecia.

Stratigraphic and geographic range. Mississippian, Viséan; Ireland (Wyse Jackson, 1996), Germany (Ernst, 2005), France (unpublished data). Mississippian, Viséan (upper Asbian); Los Santos Hill section, southwestern Spain. Mississippian (Brigantian); Caleras Bajas section, southwestern Spain.

Family Nikiforovellidae Gorjunova, 1975

Genus Nikiforovella Nekhoroshev, 1948

Type species. Nikiforovella alternata Nekhoroshev, 1948, by original designation. Lower Carboniferous; Altai, Russia.

Diagnosis. Branched colonies. Autozooecia diverging at low angles from distinct median axis. Hemisepta absent, diaphragms rare. Autozooecial walls laminated, with dark zooecial boundaries. Metazooecia few between longitudinally successive autozooecial apertures; acanthostyles common to abundant. Longitudinal ridges absent.

Comparison. Nikiforovella Nekhoroshev, 1948 is similar to Streblotrypella Nikiforova, 1948, but differs from it mainly in the shape of autozooecia, that bend at higher angles in the exozone, the lack of longitudinal ridges, and in possessing of styles that can be absent in Streblotrypella.

Stratigraphic and geographic range. Upper Devonian to Upper Permian; worldwide.

Nikiforovella multipitata Trizna, 1958

(Figs 8g, 9a-9d; Table 5)

1958 Nikiforovella multipitata Trizna; p. 226-228, pl. 62 , figs $7-15$.

Material. Cal 2b/10, Col/7-8, Col/13-1, AL/1-3.

Table 5. Descriptive statistics of Nikiforovella multipitata Trizna, 1958. Abbreviations as for Table 1.

\begin{tabular}{lcccccc}
\hline & $\mathbf{N}$ & $\mathbf{X}$ & SD & CV & MIN & MAX \\
\hline $\begin{array}{l}\text { Aperture width, mm } \\
\text { Autozooecial aperture }\end{array}$ & 5 & 0.10 & 0.014 & 14.14 & 0.08 & 0.12 \\
spacing along branch, mm & 5 & 0.38 & 0.023 & 5.97 & 0.36 & 0.41 \\
Metazooecia diameter, mm & 15 & 0.025 & 0.005 & 20.38 & 0.015 & 0.035 \\
Acanthostyle diameter, mm & 15 & 0.028 & 0.004 & 14.41 & 0.020 & 0.035 \\
\hline
\end{tabular}

Description. Colonies branched, 0.63-1.05 $\mathrm{mm}$ in diameter, with endozones $0.31-0.55 \mathrm{~mm}$ and exozones $0.16-0.30 \mathrm{~mm}$ wide. Autozooecia tubular, growing in a spiral pattern from a distinct median axis at angles of $23-26^{\circ}$ in endozones, abruptly bending in exozones and intersecting colony surface at angles of $72-77^{\circ}$ with triangular to rhombic transverse section in the endozone. Autozooecial apertures oval, arranged in regular diagonal rows on branches. Autozooecial diaphragms absent. Autozooecial walls granular, 0.005-0.015 mm thick in endozone; finely laminated, merged, in exozone. Metazooecia originating at the base of the exozone, 5-8 arranged in clusters between longitudinally successive autozooecial apertures. Acanthostyles large with distinct hyaline cores and laminated sheaths, 3-5 arranged between longitudinally successive autozooecial apertures.

Comparison. Nikiforovella multipitata Trizna, 1958 differs from $N$. ulbensis Nekhoroshev, 1956 from the 

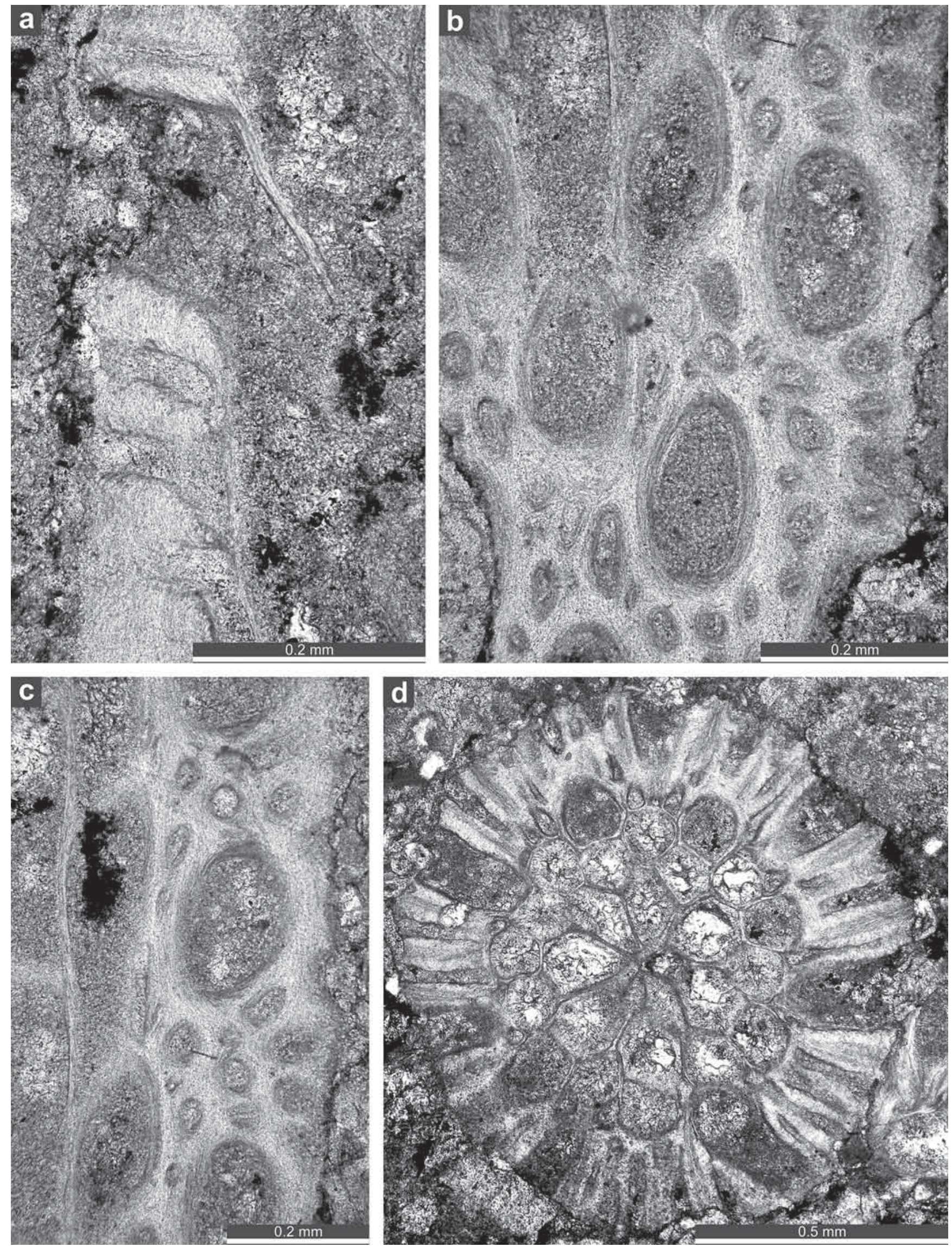

Figure 9. Nikiforovella multipitata Trizna, 1958: a) Branch longitudinal section, Cal/2b. b-c) Tangential section showing autozooecial apertures, metazooecia, and acanthostyles, Cal/2b. d) Branch transverse section, Cal/2b. 
Mississippian of Altai and Northern Russia by having less abundant metazooecia, fewer acanthostyles, and more closely spaced autozooecial apertures along branches $(0.36-0.41 \mathrm{~mm}$ vs. $0.50-0.60 \mathrm{~mm}$ in $N$. ulbensis). Nikiforovella multipitata differs from $N$. alternata Nekhoroshev, 1956 from the Mississippian of Altai in having 5-8 metazooecia and 3-5 acanthostyles between longitudinally successive autozooecial apertures, whereas in $N$. alternata 2 metazooecia and 2 acanthostyles occur between apertures.

Stratigraphic and geographic range. Mississippian, Tournaisian-Viséan; Russia, Siberia (Kuznetzk Basin). Mississippian (upper Asbian); El Almendro section, southwestern Spain. Mississippian, Viséan (AsbianBrigantian); El Collado, southwestern Spain. Mississippian (Brigantian); Caleras Bajas section, southwestern Spain.

\section{DISCUSSION}

The Lower Carboniferous (Mississippian) bryozoan fauna of southwestern Spain contains eight species: the cystoporates Fistulipora sp., Fistulipora incrustans (Phillips, 1836), and Glyptopora michelinia (Prout, 1860), the trepostomes Stenophragmidium paramirandum Ernst et al., 2005, Stenophragmidium crassimularis (Lee, 1912), and Hinaclema hinaensis Sakagami \& Sugimura, 1987, and the cryptostomes Pseudonematopora planatus Wyse Jackson, 1996 and Nikiforovella multipitata Trizna, 1958.

Carboniferous bryozoans can be important in biostratigraphy (Bancroft, 1987) and are certainly useful in palaeobiogeographic reconstructions (Ross, 1981). Some species described herein, are indicative of the Mississippian in Europe, including Fistulipora incrustans (Phillips, 1836) and Pseudonematopora planatus Wyse Jackson, 1996, both of which are restricted to the Viséan. Stenophragmidium crassimularis (Lee, 1912) also occurs in Viséan deposits of the British Isles, but we found this species in the lower Serpukhovian (Pendleian) of southwestern Spain.

Glyptopora michelinia (Prout, 1860) was originally recorded from the Mississippian (Viséan) of the USA. The genus Glyptopora is known primarily from the Mississippian of the USA, with ranges of three species extending into the Pennsylvanian (Bashkirian-Kasimovian). One species, G. kasakhstanica Nekhoroshev, 1953, is known from ViséanSerpukhovian deposits of Kazakhstan.

The genus Hinaclema is also indicative of the Viséan, with both known species (H. hinaensis and $H$. sakagamai) from the Viséan of Japan and Tajikistan, respectively.

Finally, Nikiforovella multipitata Trizna, 1958 is known from the Mississippian (Viséan) of Siberia and Stenophragmidium paramirandum Ernst et al., 2005 from the Pennsylvanian (Westphalian A/B) of NW Spain.

\section{ACKNOWLEDGMENTS}

AE thanks Deutsche Forschungsgemeinschaft (DFG) for financial support (project ER 278/6.1). Field work was funded by the Spanish Ministerio de Innovación y Ciencia (research project CGL2009-10340/BTE) and SantanderUCM Research group 910231. We thank also Patrick Wyse Jackson, Dublin, and Joseph F. Pachut, Indianapolis, for their helpful and constructive reviews. This paper is a contribution to the IGCP 596.

\section{REFERENCES}

Anstey, R.L. \& Perry, T.G. 1970. Biometric procedures in taxonomic studies of Paleozoic bryozoans. Journal of Paleontology, 44 (3), 383-398.

Astrova, G.G. 1964. A new order of the Paleozoic Bryozoa. Paleontologicheskiy Zhurnal, 1964 (2), 22-31 [In Russian].

Astrova, G.G. \& Morozova, I.P. 1956. On systematics of the bryozoans of the Order Cryptostomata. Doklady Akademii Nauk SSSR, 110(4), 661-664 [In Russian].

Balakin, G.V. 1974. Pseudonematopora, novyj rod rannekamennougol'nykh mshanok Paleontologicheskiy Zhurnal 1974 (4), 130-132 [in Russian; English translation: Pseudonematopora, a new Early Carboniferous bryozoan genus. Paleontological Journal, 8, 557-559].

Bancroft, A.J. 1987. Biostratographical potential of Carboniferous Bryozoa. Courier Forschungsinstitut Senkenberg, 98, 193-197.

Bancroft, A.J. \& Wyse Jackson, P.N. 1995. Revision of the Carboniferous bryozoan Fistulipora incrustans (Phillips, 1836), with remarks on the type species of Fistulipora M'Coy, 1849. Geological Journal, 30, 129-143.

Bassler, R.S. 1911. The early Paleozoic Bryozoa of the Baltic Provinces. Bulletin of the Smithsonian Institution, United States National Museum, 77, 1-382.

Bassler, R.S. 1952. Taxonomic notes on genera of fossil and Recent Bryozoa. Journal of the Washington Academy of Sciences, 42, 381-385.

Borg, F. 1926. Studies on Recent cyclostomatous Bryozoa. Zoologiska Bidrag från Uppsala, 10, 181-507.

Cleary, D. \& Wyse Jackson, P.N. 2007. Stenophragmidium Bassler, 1952 (Trepostomida: Bryozoa) from the Mississippian of Ireland and Britain. Irish Journal of Earth Sciences, 25 (19), 1-25.

Cózar, P. 1998. Bioestratigrafía con foraminíferos del Carbonífero Inferior del sector Norte del Área del Guadiato (Córdoba). PhD Thesis, Universidad Complutense de Madrid, 1-590 (unpublished).

Cózar, P. \& Rodríguez, S. 1999. Propuesta de nueva nomenclatura para las unidades del Carbonífero Inferior del Sector Norte del Área del Guadiato (Córdoba). Boletín Geológico y Minero, 110, 237-254. 
Cózar, P. \& Rodríguez, S. 2000. Caracterización estratigráfica y sedimentológica del Viseense superior de Sierra Boyera (Área del Guadiato, SO de España). Sociedad Geológica Española, 13, 91-104.

Cózar, P. \& Rodríguez, S. 2001. Precisiones sedimentológicas y bioestratigráficas en la Unidad el Fresnedoso, Área del Guadiato (Mississippiense, SO España). Boletín de la Real Sociedad de Historia Natural (Sección Geológica), 96, 69-84.

Cózar, P. \& Rodríguez, S. 2004. Pendleian (early Serpukhovian) marine carbonates from SW Spain: sedimentology, biostratigraphy and depositional model. Geological Journal, 39 (1), 25-47.

Crockford, J. 1947. Bryozoa from the Lower Carboniferous of New South Wales and Queensland. Proceedings of the New South Wales Linnean Society, 72, 1-48.

Crockford, J. 1957. Permian Bryozoa from the Fitzroy Basin, Western Australia. Bulletin of Bureau of Mineral Resources, Geology and Geophysics, Australia, 34, 1-134.

Dunaeva, N.N. 1964. K faune nizhnekamennougol'nykh trepostomat donetzkogo basseina [The Early Carboniferous trepostome fauna from the Donetz Basin]. Trudy Instituta Geologii Akademii Nauk Ukrainskoi SSR, seriya stratigrphiya i paleontologiya, 48 (2), 104-141 [In Russian].

Dunaeva, N.N. \& Morozova, I.P. 1967. Osobennosti razvitiya i sistemaicheskoe polozhenie nekotorykh pozdnepaleozojskikh trepostomat. Paleontologicheskiy Zhurnal, 1967 (4), 86-94, [in Russian; English translation: Evolution and systematic position of some Paleozoic Trepostomata. Paleontological Journal, 1 (4), 64-72].

Ehrenberg, C.G. 1831. Symbolae Physicae, seu Icones et descptiones Corporum Naturalium novorum aut minus cognitorum, quae ex itineribus per Libyam, Aegiptum, Nubiam, Dongalaam, Syriam, Arabiam et Habessiniam, studia annis 1820-25, redirent. Pars Zoologica, 4, Animalia Evertebrata exclusis Insectis. Berolini, 10 pls.

Ernst, A. 2000. Permian bryozoans of the NW-Tethys. Facies, 43, 79-102.

Ernst, A. 2005. Lower Carboniferous Bryozoa from some localities in Sauerland, Germany. In: Bryozoan Studies 2004 - Proceedings of the 13th International Bryozoology Association Conference, Concepcion, Chile, January 2004 (eds. Moyano, G.I., Cancino, J.M. \& Wyse Jackson, P.N.). Balkema Publishing House, London, pp. 49-62.

Ernst, A., Schäfer, P. \& Reijmer, J.J.G. 2005. Stenolaemate Bryozoa from the Upper Carboniferous of the Cantabrian Basin, Northern Spain. Senckenbergiana lethaea, 85 (2), 307-317.

Ernst, A. \& Winkler Prins, C.F. 2008. Pennsylvanian bryozoans from the Cantabrian Mountains (northwestern Spain). Scripta Geologica, 137, 1-123.

Gómez-Herguedas, A. \& Rodríguez, S. 2005. Estudio de los corales rugosos con disepimentos del Serpujoviense (Mississippiense) de la sección de La Cornuda (Córdoba, España). Coloquios de Paleontología, 55, 51-102.
Gómez-Herguedas, A. \& Rodríguez, S. 2008. Paleoenvironmental analysis based on rugose corals and microfacies: a case study at La Cornuda section (early Serpukhovian, Guadiato Area, SW Spain). Lethaia, 42, 39-54.

Gorjunova, R.V. 1975. Permskie mshanki Pamira [Permian Bryozoa of Pamir]. Trudy Paleontologicheskogo Instituta Akademii Nauk SSSR, 148, 1-125 [in Russian].

Gorjunova, R.V. 1988. Novyye kamennougol'nyye mshanki Gobiyskogo Altaya [New Carboniferous bryozoans of the Gobi Altai]. In: Novyye iskopayemyye bespozvonochnyye Mongolii [New species of fossil invertebrates of Mongolia] (ed. Rozanov, A.Y.). Trudy - Sovmestnaya SovetskoMongol'skaya Paleontologicheskaya Ekspeditsiya, 33, pp. 10-23.

Gorjunova, R.V. 1996. Phylogeny of the Paleozoic Bryozoa. Trudy Paleontologicheskogo Instituta R. A. N., 267, 1-161, Nauka, Moscow [In Russian].

Hageman, S. J. 1993. Effects of nonnormality on studies of the morphological variation of a rhabdomesine bryozoan, Streblotrypa (Streblascopora) prisca (Gabb and Horn). The University of Kansas Paleontological Contributions, 4, 1-13.

Hall, J. 1883. Bryozoans of the Upper Heidelberg and Hamilton groups. Transactions of the Albany Institute, 10, 145-197.

Hall, J. \& Simpson, G.B. 1887. Corals and Bryozoa; text and plates containing descriptions and figures of species from the Lower Heidelberg, Upper Heidelberg and Hamilton Groups. In: Natural History of New York, Pt. 6, Paleontology of New York, 6. Ch. van Benthuysen \& Sons, Albany: xxvi + 298 p.

Lee, G.W. 1912. The British Carboniferous Trepostomata. Memoirs of the Geological Survey of Great Britain, 1 (3), 135-195.

Lonsdale, W. 1844. Description of six species of corals from the Palaeozoic formation of Van Diemen's Land. In: Geological observations on the Volcanic Islands visited during the voyage of H. M. S. "Beagle" (C. Darwin), 161-169. Smith, Elder \& Co., London.

Nicholson, H.A. 1881. On the structure and affinities of the genus Monticulipora and its subgenera with critical descriptions of illustrative species. Edinburgh.

M'Coy, F. 1849. On some new genera and species of Palaeozoic Corals and Foraminifera. Annals and Magazine of Natural history, 3 (2), 119-136.

McKinney, F.K. 1972. Nonfenestrate Ectoprocta (Bryozoa) of the Bangor Limestone (Chester) of Alabama. Geological Survey of Alabama Bulletin, 98, 1-144.

Mamet, B. L. 1974. Une zonation par foraminifères du Carbonifère inférieur de la Téthys occidentale, In: Comptes Rendus du 7 me Congrès International de Stratigraphie et de Géologie du Carbonifère, Krefeld 1971, volume 3, pp. 391-408.

Meek, F.B. \& A.H. Worthen. 1865. Notice on some new types of organic remains from the Coal Measures of Illinois. Proceedings of the Academy of Natural Sciences of Philadelphia, 18, 46-51. 
Morozova, I.P. 1970. Late Permian Bryozoa. Trudy Paleontologicheskogo Instituta Akademii Nauk SSSR, 122, 1-347 [in Russian].

Munro, M. 1912. Description of some new forms of trepostomatous Bryozoa from the Lower Carboniferous rocks of the North-Western Province. Quarterly Journal of the Geological Society, 272, 574-579.

Nakrem, H.A., Błażejowski, B. \& Gaździcki, A. 2009. Lower Permian bryozoans from southern and central Spitsbergen, Svalbard. Acta Palaeontologica Polonica, 54 (4), 677-698.

Nekhoroshev, V.P. 1932. Die Bryozoen des deutschen Unterkarbons. Abhandlungen der Preussischen Geologischen Landesanstalt, Neue Folge, 141, 1-74.

Nekhoroshev, V. P. 1948. Devonian Bryozoa of the Altai. (Paleontologiya SSSR: Devonskie mshanki Altaya). Paleontology of the USSR, 3, 1-172 [in Russian].

Nekhoroshev, V. P. 1953. Nizhnekamennougol'nye mshanki Kazakhstana [Lower Carboniferous Bryozoa of Kazakhstan]. Trudy Vsesoyuznogo Nauchno-Issledovatelskogo Instituta (VSEGEI) (1953), 1-183 [in Russian].

Nekhoroshev, V.P. 1956. Nizhnekamennougolnye mshanki Altaya i Sibiri [Lower Carboniferous Bryozoa of Altai and Siberia]. Trudy Vsesoyuznogo Nauchno-Issledovatelskogo Instituta (VSEGEI), n. s., 13, 1-420 [in Russian].

Nikiforova, A.I. 1948. Nizhne-kamennougolnye mshanki Karatau [Lower Carboniferous Bryozoa of Karatau]. AN KazSSR, Alma-ata [in Russian].

Phillips, J. 1836. Illustrations of the geology of Yorkshire. Pt. 2. The Mountain Limestone District. John Murray, London.

Prout, H.A. 1860. Fourth series of descriptions of Bryozoa from the Paleozoic rocks of western states and territories. Transactions of St. Louis Academy of Sciences, series 3, 571-581.

Prout, H.A. 1866. Descriptions of Polyzoa from the Paleozoic rocks. Illinois State Geological Survey, 2, 412-423.

Rodríguez, S. \& Rodríguez-Curt, L. 2002. Reconstrucción de una plataforma carbonatada Viseense no preservada en el área del Guadiato (Córdoba, SO de España). Geogaceta, 32, 283-286.

Rodríguez, S., Arribas, M.E., Bermúdez-Rochas, D.D., Calvo, A., Cózar, P., Falces, S., Hernando, J.M., Mas, J.R., Moreno-Eiris, E., De La Peña, J.A., Perejón, A., Sánchez-Chico, F. \& Somerville, I.D. 2007. Stratigraphical and palaeontological synthesis of the Sierra del Castillo succession (late Viséan, Córdoba, SW Spain). Proceedings of the XVth International Congress on Carboniferous and Permian Stratigraphy, Royal Academy of Sciences, Amsterdam, pp. 205-216.
Rodríguez, S., Arribas, M.E., Comas Rengifo, M.J., De la Peña, J.A., Falces, S., Gegundez, P., Martínez Chacon, M.L., Moreno-Eiris, E., Perejon, A., Sanchez, J.L. \& Sanchez-Chico, F. 1992. Análisis paleontológico y sedimentológico de la cuenca carbonífera de los Santos de Maimona (Badajoz). Estratigrafía. Coloquios de Paleontología, 44, 23-48.

Rodríguez, S., Arribas, M.E., Falces, S., Moreno-Eiris, E., De la Peña, J.A. 1994. The Siphonodendron Limestone of Los Santos de Maimona Basin: development of an extensive reef-flat during the Viséan in Ossa-Morena. SW Spain. Courier Forschungsinstitut Senckenberg, 172, 203-214.

Ross, J.R.P. 1981. Biogeography of Carboniferous ectoproct Bryozoa. Palaeontolegy, 24 (2), 313-341.

Sakagami, S. \& Sugimura, A. 1987. Hinaclema, a new Carboniferous bryozoan genus from the Hina Limestone, southwest Japan. Proceedings Japan Academy, B (Physical and Biological Sciences), 63, 246-249.

Schastlivtseva, N.P. 1991. Pervaya nachodka v SSSR kamennougolnogo roda Hinaclema (mshanki) [The first find of the Carboniferous genus Hinaclema (bryozoans) in the USSR]. Paleontologicheskii Zhurnal, 1, 118-120.

Shulga-Nesterenko, M.I. 1955. Kamennougol'nye mshanki Russkoi platformy [Carboniferous Bryozoa of the Russian Platform]. Trudy Paleontologicheskogo Instituta Akademii Nauk SSSR, 57, 1-207 [in Russian].

Trizna, V.B. 1958. Rannekamennougolnye mshanki Kuznetzkoi kotloviny [Early Carboniferous bryozoans of the Kuznetz depression]. Trudy Vsesoyuznogo Neftanogo NauchnoIssledovatel'skogo Geologo-Razvedochnogo Institua, 122, 1-436 [in Russian].

Ulrich, E.O. 1882. American Palaeozoic Bryozoa. The Journal of the Cincinnati Society of Natural History, 5, 121-175, 233-257.

Ulrich, E.O. 1884. American Palaeozoic Bryozoa. The Journal of the Cincinnati Society of Natural History, 8, 24-51.

Ulrich, E.O. 1890. Palaeozoic Bryozoa: III. Report of the Geological Survey of Illinois, 8, 283-688.

Vine, G.R. 1884. Fourth report of the Committee appointed for the purpose of reporting on fossil Polyzoa. Reports of the 53rd meeting of the British Association for Advances in Science: 161-209.

Waagen, W. \& Wentzel, I. 1886. Salt Range Fossils. Pt. Coelenterata. Memoir of the Geological Survey of India, Palaeontologica Indica, 13, 835-924.

Wyse Jackson, P.N. 1996. Bryozoa from the Lower Carboniferous (Viséan) of County Fermanagh, Ireland. Bulletin of the Natural History Museum, London (Geology), 52, 119-171.

Young, J. 1883. On Ure's “Millepore”. Tabulipora (Cellepora) Urii, Flem. Annals and Magazine of Natural History, 12 (5), 154-158. 
